\title{
Domestic Politics of Trade Policy
}

\author{
Michaël Aklin $\quad$ Eric Arias $\quad$ Emine Deniz $\quad$ B. Peter Rosendorff
}

\begin{abstract}
Domestic politics shapes international trade policy, but exactly how and why remains an open question. We explore the cutting edge literature that focuses on how agents' interests are formed, whose interests are organized, and how those interests interact with each other via domestic political institutions to generate both trade policy and international cooperation over trade more broadly. In turn, trade policies operate as a feedback loop. International cooperation via international organizations, treaties, and more informal regimes, generates information which affects the domestic politics conflict in substantive ways. We explore each of these topics and suggest future research paths.
\end{abstract}

\section{Introduction}

That domestic politics matters for trade policy is now a well established trope in both economics and political science. International trade and international relations more generally are not determined by a sole national executive, acting autonomously and isolated from the pressures of domestic political interests when choosing tariff levels, health and safety rules and regulations, or other elements of trade policy. Instead, trade policy, like any other domain of public policy, is determined by the interplay of domestic economic interests, domestic political institutions, and the information that is available to all involved players.

The research agenda in the recent period has been to identify not merely that domestic politics matters, but instead to determine why it matters. This means, essentially, understanding who the important players in the trade policy process, and what their interests or preferences are. These preferences vary across groups, be they industries, factor-owners or an agent's role as producer or consumer, or as an upstream or downstream firm. The groups themselves may or may not be organized politically, and may or may not have political influence or clout. The ability of any group to influence a policy outcome or the trade 
policy agenda will depend on the structure and nature of the domestic political process the set of mechanisms that mediate political conflict, and transmit preferences into policy, which we call institutions. Finally, the international arrangements that are made to govern these trade policies in themselves generate information that impacts both the political strength of the domestic interested parties and the trade policies that are chosen. There is in a sense, a "feedback-loop" leading back from trade policies, agreements, and international organizations that impacts the political influence of the domestic interests.

To understand how domestic politics matters for trade policy, we must recognize the crucial interaction of interests and institutions on trade policy, and of information generated by implemented trade policy on domestic interests (mediated by the domestic institutions). In what follows we explore the cutting edge literature that focuses on how interests are formed, whose interests are organized, and how those interests interact with each other via domestic political institutions to generate both trade policy and international cooperation over trade more broadly. International cooperation via international organizations, treaties, and more informal regimes, in turn generate information which affects the domestic politics conflict in substantive ways.

\section{Interests: Individuals, Groups and their Preferences}

International trade theory offers a natural starting point for the political economy of protection. The classic Heckscher-Ohlin model of trade in which a country's factor endowments play a crucial role in determining the pattern of trade also allows clear predictions of the effect of trade (or barriers to trade) on the relative incomes of factor owners. This classbased model of trade generates, via the Stolper-Samuelson theorem, the very neat claim that barriers to trade will benefit the owners of the relatively scarce factor, and harm the owners of the relatively abundant factor. Barriers to trade in the US, for example, benefit the unskilled labor and harm skilled labor - since the US has relatively less unskilled labor than most of its trading partners (Leamer, 1984).

Early approaches took these groups and their induced preferences over trade policy as given. It seemed a reasonable assumption that unskilled labor in the US would be opposed to free trade agreements, while owners of capital would be in favor. These preferences over trade

policy were "induced" because they emerged from the underlying preferences over income and consumption (i.e., more income is better; Persson and Tabellini 2000). Attitudes to trade therefore are closely correlated with factor-ownership or class. 
The Ricardo-Viner (specific factors) model of international trade induces preferences over trade policy along industry lines, instead. Industries that expand due to international trade see their fortunes increase along with their increased exports; industries that suffer due to import-competition are expected to oppose liberalization. This model (in which some capital is fixed in an industry, and unable to migrate as economic conditions change) predicts that induced preferences are determined by an individual's location within an industry rather than the class to which she belongs.

Both models make very clear that trade (and conversely, protection) redistribute income from one group to another. Recent scholarship has made significant progress in identifying the politically relevant groups and their interests. A key aspect of this endeavor is to understand how those interests are aggregated and how they influence policymaking. We discuss this work below by looking at individual level preferences first, industry and firm level preferences next, and finally, how they go about making policy demands.

\subsection{Individuals and Public Opinion}

Studies of individual level trade preferences have grown rapidly over the past two decades thanks to improvements in survey data collection. Overall, this research has contributed in two ways: first, by testing the predictions of international trade theory, and second by finding complementary accounts of the determinants of trade policy attitudes, giving rise to a debate on the relative importance of material versus non-material factors.

Measuring skills by education and occupation wages, the predictions of the HeckscherOhlin model are supported by U.S. (Scheve and Slaughter, 2001) and cross-country survey data (Mayda and Rodrik, 2005). In contrast, evidence supporting the Ricardo-Viner model is mixed. Mayda and Rodrik (2005) find evidence for this model, while Scheve and Slaughter (2001) do not.

Scholars also sought to uncover non-economic determinants of trade policy attitudes. Some authors argue that local attachments and nationalistic sentiments are correlated with support for protectionist policies (Mansfield and Mutz, 2009). Others argue that the effect of education on individual preferences goes beyond skills acquisition. Education may expose people to economic and cosmopolitan ideas that emphasize the benefits of globalization, and thus have an indirect effect on trade policy preferences (Hainmueller and Hiscox, 2006). Finally, education also mediates the effects of issue framing on trade policy preferences. Using a survey experiment, Hiscox (2006) shows that the wording of survey questions has systematic biases in responses, but these biases are weaker among highly educated individuals. 
Scholars emphasizing the role of material interests did not take long to respond. Ardanaz, Murillo, and Pinto (2013) replicate Hiscox's (2006) design explicitly considering the impact of trade on individuals' income. To proxy for this effect they use the respondent's region, that is, whether she lives in an import-competing area (which stands to lose from trade) or not. They find that these material concerns are indeed the main explanatory factor determining a person's sensitivity of framing effects, even when controlling for education. This is because those individuals whose income is closely affected by trade have stronger priors about the effect of trade openness on their own income, making them less sensitive to informational cues.

\subsection{Firms and Induced Trade Policy}

Social scientists have studied trade at a second level of analysis, from the perspective of firms and industrial sectors. This aggregation is natural for various reasons. First, firms are well-organized institutions and thus often able to formulate policy demands Grossman and Helpman, 1994). Second, they have access to vast resources, which is helpful when lobbying politicians. Finally, firms and entire industries may be directly affected by trade policies.

The last point is particularly salient and informed early models of industry trade preferences (Milner, 1999). The Ricardo-Viner trade model predicts that if some factors of production are tied to their industries, then trade preferences will be defined along industrial lines. Thus, the relevant units are industries, and what individuals want (if they matter at all) will depend on who their employer is. Of course, factor mobility may change over time (Hiscox, 2001). Furthermore, industries' preferences may evolve. As trade barriers go down, firms may buy more inputs from abroad, changing their priorities (Milner, 1988). Nonetheless, a body of evidence suggests that domestic trade conflicts have pitted industries against each other. Hiscox (2001) provides historical evidence from six Western countries and shows that periods of low factor mobility coincide with strong industry-based lobbying.

Similarly, using survey data from Norway, Alt et al. (1999) show that lobbying increases as a firm's asset becomes more specific.

Nevertheless, these models had little to say about the rise of intra-industry trade Helpman, 1999). Ricardo-Viner and Heckscher-Ohlin expect countries to specialize, trade being the mechanisms that enables them to do so. In reality, however, large trade flows occur between very similar countries. New trade theory (and new new trade theory, its recent avatar) filled this gap (Melitz, 2003). These models rejected the view that firms can be thought of as homogeneous units within industries. Goods are now differentiated, allowing countries to 
simultaneously import and export cars, for instance. The implication is that the relevant unit of analysis is not an industry, but the firms that constitute it.

Thus, attention has shifted from industries to firms. The decision to lobby, for instance, is now modeled at the firm level (Gilligan, 1997). Even when they operate in the same sector, firms vary along numerous dimensions. Melitz (2003) shows that variation in productivity within an industry can affect a firms' stance with respect to exports, and hence can induce preferences over trade policy. In a similar fashion, some firms may have access to better technology (Yeaple, 2005). Overall, highly productive firms are more likely to be exporters; least productive firms in an industry are likely to be import-competing. When barriers to trade fall, it is the least competitive firms that exit the industry, and it is these firms that are more likely to be politically active in search of protection.

\subsection{Lobbies}

While identifying individual and firm preferences is the first step towards a complete model of trade policy, the next one is to specify how they influence policymaking. In particular, how do these players overcome the so-called coordination problem and make policy demands (Olson, 1965)? What we now regard as an endogenous process - lobby formation - was mainly black-boxed until the seminal work by Grossman and Helpman (1994).

The main idea behind Grossman and Helpman's (1994) theory of endogenous protection is best described by the paper's title: "Protection for Sale." It argues that special interest groups can use campaign contributions to incentivize politicians to adopt favorable trade policies. The paper describes a contribution schedule as the announcement by a lobby of the amount of campaign contributions it is willing to make in exchange for a given policy. The equilibrium is then defined as "a set of contribution schedules such that each lobby's schedule maximizes the aggregate utility of the lobby's members, taking as given the schedules of other lobby groups." All else being equal, it is industries' relative importing or exporting nature that will affect their decision to deviate from free trade.

While Grossman and Helpman (1994) takes the existence of organized groups as given, Mitra (1999) endogenizes the lobby formation process. He shows that the equilibrium trade subsidy is not always positively related to the government's affinity for campaign contributions. This is because high affinity for contributions leads to the formation of a large number of opposing lobbies which cancel each other out. He also finds that industries with large capital stocks, facing inelastic demand functions, with few capital owners, and that are geographically concentrated are more likely to get organized. Bombardini (2008) builds 
on this approach to argue that the "Protection for Sale" paradigm cannot account for the effect of relative firm size because it treats lobbies as unitary actors. Instead, she models individual firms choosing the amount of resources allocated to campaign contributions. She shows that (i) it is efficient for the largest firms in a sector to form the lobby, and (ii) the degree of protection extended to a given sector increases with the number of firms above a given size in that sector. Empirically, this model explains a larger share of the variation in protection across sectors than the "Protection for Sale" mechanism.

A second source of heterogeneity is the relative reliance of firms on capital or labor. In Mitra (2000), heterogeneity arising from capital-rich and labor-rich industries results in an equilibrium under which capitalists might prefer protection to subsidies. Lobbying for protection instead of subsidies can mitigate the coordination problem for capital-rich industries. On the other hand, empirical evidence suggests that international competition increases the likelihood of lobbying for subsidies for industries with high specialization, that is, less mobility (Alt et al., 1999).

\section{Institutions}

Early work pointed to the important determinative effects of domestic political institutions on trade policy. To quote Alt and Gilligan (1994, p.166) "anyone theorizing about the state confronts issues arising from both institutions and economic structure in figuring out distributional effects." In this section we elaborate on these issues, first by looking at the differential effects of regime type, and then by discussing the consequences of institutional variation between democracies.

\subsection{Regime Type: Democracies and Autocracies}

Democracies are shown to trade more freely (Rosendorff, 2006), and are generally more cooperative when it comes to international commercial policy. Explanations for this behavior emerge from models highlighting separation of powers (Mansfield, Milner, and Rosendorff, 2000; Martin, 2000), electoral accountability (Mansfield, Milner, and Rosendorff, 2002; Milner, Rosendorff, and Mansfield, 2004), the presence of veto players (Mansfield, Milner, and Pevehouse, 2007; Mansfield and Milner, 2012), and an increased willingness to use trade agreements to improve transparency (Hollyer and Rosendorff, 2012). Milner and Kubota (2005) argue that as democracy has emerged in labor-rich countries, Stolper-Samuelson effects would lead to an increased demand for freer trade. Electorally accountable leaders in 
labor-rich countries lower trade barriers as democracy expands. In a more subtle vein, Kono (2006) argues that democracy induces politicians to reduce transparent trade barriers but also to replace them with less transparent ones.

Other characteristics of democratic polities have also emerged as important determinants of trade policy. For instance, electoral accountability increases the need for governments to be able to provide temporary relief for influential sectors and industries without violating international obligations. This to preserve a cooperative trading stance in international relations. Rosendorff and Milner (2001) shows that international trade agreements are designed to permit accountable governments (more likely to be democracies) temporary relief from their obligations in the form of the safeguard and the antidumping codes (see also Rosendorff 1996). The WTO's dispute settlement procedures play a similar role (Rosendorff, 2005).

\subsection{Intrademocratic variation}

\subsubsection{Electoral Rule}

Institutional variation between democracies are relevant as well. Majoritarian electoral systems impart a protectionist bias to fade policy (Grossman and Helpman, 2005). This echoes Rogowski (1987) who suggested that large district proportional representation parliamentary systems are best for protecting free(r) trade. In contrast, Ehrlich (2007) suggests that once the number of parties in government and the number of electoral districts are controlled for, proportional representation has no impact on trade policy. Evans (2009) tests Grossman and Helpman's 2005) claim and finds that countries with majoritarian systems indeed appear to have higher average tariffs than do countries with proportional systems. This result holds after controlling for country-specific characteristics, such as a country's legal origins, colonial history, and geographic location. Rickard (2012) expands the investigation to find the protectionist bias in majoritarian systems extends beyond tariffs to include state production subsidies too.

\subsubsection{Parties and Party Discipline}

Party ideology, and the degree to which party members are required to vote the party line affect a state's protectionist stance. Dutt and Mitra (2005) establish that, vis-à-vis rightwing governments, left-wing leaders adopt more protectionist trade policies in capital-rich countries, but adopt more pro-trade policies in labor-rich countries. Similarly, Milner and Judkins (2004) find that right-wing parties take more free trade stances than do left ones in 
developed countries.

District marginality interacts with party discipline in crucial ways (McGillivray, 1997; McGillivray and Smith, 1997). In majoritarian systems with high levels of party discipline, trade policies will favor voters in marginal districts; with low party discipline, trade policies will favor large, electorally dispersed industries. Hence, industries concentrated in marginal districts are expected to be the least favorably protected while large industries geographically dispersed over many electoral districts receive the most favorable protection.

\subsubsection{Divided Government and Veto Players}

The structure of negotiation over trade policy between the executive and legislative branches has several implications as well. If presidents can negotiate agreements that do not require congressional approval they may still decide to engage in that domestic negotiation as a signal of intent to comply with it (Martin, 2005). However, the terms of that negotiation will partially reflect protectionist preferences of the legislature branch (Dai, 2006). In particular, divided government requires the executive to assemble a congressional majority, thus constraining her to provide higher protection (Lohmann and O'Halloran, 1994). Moreover,

divided government not only impacts the depth of international agreements, it also increases the probability of ratification failures (Milner and Rosendorff, 1997).

Others branches of government also influence trade policy. The key aspect here is the presence of veto players, that is, actors who might block the ratification of a trade treaty, and thus impose new constrains during the negotiation. Evidence shows that an increase in the number of veto players has two main consequences: first, it increases the time that takes to ratify international trade agreements (Mansfield and Milner, 2012), and second, reduces the likelihood of signing new ones (Mansfield, Milner, and Pevehouse, 2007).

\section{Information: The Feedback Loop}

So far, we explained trade policies as a function of domestic politics. However, trade, operating as a feedback loop, also shapes domestic politics. Specifically, trade and trade-related institutions may provide information to domestic audiences and enable policymakers to send them signals.

Economies fluctuate along boom and bust cycles. Generally, domestic audiences are imperfectly informed about the responsibility of their leaders for these busts. Poor performances may be due to the stochastic nature of the economy but they could also be due to 
their leaders' poor policies. For instance, high trade barriers create inefficiencies that hurt economic productivity. In the absence of third party monitoring, audiences may be unable to attribute responsibility. International organizations and treaties provide a solution to this information problem (Mansfield, Milner, and Rosendorff, 2002). International institutions generally monitor their members' behavior and include a system to address complaints about non-compliance. This is the case, for instance, for trade institutions such as the WTO. Domestic leaders who worry about being accused of poor economic management may thus have an incentive to join these institutions. Since bad economic governance (such as increasing undue subsidies to favored industries) would likely trigger a complaint, Mansfield, Milner, and Rosendorff (2002) argue that international institutions provide information to domestic audiences. The absence of complaint is interpreted as sound policies, while accusations of cheating are interpreted as poor policies.

A related stream of literature focuses on policymakers' ability to send signals to domestic audiences. Political leaders may be unable to credibly commit to an optimal policy. For instance, governments may be unable to enforce a reduction in trade barriers if domestic industries know that their support is important to them. In other words, governments suffer from a time inconsistency problem (Staiger and Tabellini, 1987). Joining international institutions can thus be a mechanism for governments to credibly signal to their domestic audience their commitment to good economic and trade policies (Mansfield and Pevehouse, 2006). Maggi and Rodriguez-Clare (1998) argue that this is particularly likely to occur when governments are relatively weak compared to domestic lobbies. They make the paradoxical prediction that it is countries that have strong interest groups that are the most likely to end up with freer trade.

Both the information and the signaling mechanisms depend on international events updating domestic preferences. A recent stream of literature has thus attempted to tackle whether domestic audiences pay attention to trade disputes. Drawing on Google search data, Pelc (2012) shows that the number of searches about the WTO increases in the United States when a trade dispute occurs. This is consistent with the view that domestic audiences are particularly attentive to mishaps by their government. But this ignores that domestic agents are not homogeneous, nor is their interest in trade issues always the same. Chaudoin (Forthcoming) argues that audiences are more likely to pay attention to the implications of trade disputes when macroeconomic conditions are benign. 


\section{The Next Steps}

Our review suggests that the literature is moving in three related directions. First, recent research has built on nuanced trade theories that are rooted at the micro level. New trade theory underscores the importance of disaggregating industries to understand what drives firms' preferences. Similarly, drawing on experimental methods, scholars are seeking a deeper understanding of the roots of individual views about trade. What remains to be seen is how well these models apply to countries beside the United States. In particular, future research on the preferences of firms and individuals located in developing countries may be fruitful.

The second stream of research has focused on the mediating role that institutions have on trade policies. Since trade policies have potent distributional implications, our understanding of trade politics relies heavily on studying the rules of collective decision-making. In particular, scholars have been interested both in differences between democracies and autocracies, and in variations among democracies. In comparison, trade policies in authoritarian regimes have remained relatively understudied.

Finally, scholars have sought to understand how international trade relations affect domestic politics. International institutions and trade disputes release valuable information to citizens. Future research will have to explicitly model how this information is processed by individuals and how it affects the policy-making process. Under which circumstances are citizens sensitive to new information? And does their sensitivity depend on the institutional context in which they are embedded?

\section{Biographies}

Michaël Aklin is a Ph.D. candidate in Politics at New York University. Beginning in August 2014, he will be Assistant Professor of Politics at the University of Pittsburgh. His research focuses on international and comparative political economy with applications to finance and environmental issues, and has been published in journals such as the American Journal of Political Science, International Studies Quarterly, Global Environmental Change, and Ecological Economics. WwW.pitt.edu/ aklin/

Eric Arias is a Ph.D. candidate in Politics at New York University. His interests lie in international and comparative political economy with a focus on the international sources of domestic policy.

Emine Deniz is a Ph.D. candidate in Politics at New York University. Her research interests lie in political economy and formal modeling. 
B. Peter Rosendorff is Professor of Politics at New York University. He is editor of the interdisciplinary journal, Economics and Politics and is an editorial board member of International Organization. He has held grants from the National Science Foundation, the Japan Foundation, among others. Research interests include the UN Convention Against Torture, the World Trade Organization, political economy of terrorism, bilateral trade and investment treaties. His work has been published in journals such as the American Economic Review, American Political Science Review, International Organization and Quarterly Journal of Political Science. https://files.nyu.edu/bpr1/public/

\section{References}

Alt, James E., Fredrik Carlsen, Per Heum, and Kare Johansen. 1999. "Asset Specificity and the Political Behavior of Firms: Lobbying for Subsidies in Norway." International Organization 53 (1): 99-116.

Alt, James E., and Michael Gilligan. 1994. "The Political Economy of Trading States: Factor Specificity, Collective Action Problems and Domestic Political Institutions." Journal of Political Philosophy 2 (2): 165-192.

Ardanaz, Martin, M. Victoria Murillo, and Pablo M. Pinto. 2013. "Sensitivity to Issue Framing on Trade Policy Preferences: Evidence from a Survey Experiment." International Organization 67 (2): 411-437.

Bombardini, Matilde. 2008. "Firm Heterogeneity and Lobby Participation." Journal of International Economics 75 (2): 329-348.

Chaudoin, Stephen. Forthcoming. "Audiences Features and the Strategic Timing of Trade Disputes." International Organization .

Dai, Xinyuan. 2006. "Dyadic Myth and Monadic Advantage: Conceptualizing the Effect of Democratic Constraints on Trade." Journal of Theoretical Politics 18 (3): 267-297.

Dutt, Pushan, and Devashish Mitra. 2005. "Political Ideology and Endogenous Trade Policy: An Empirical Investigation." The Review of Economic and Statistics 87 (1): 59-72.

Ehrlich, Sean D. 2007. "Access to Protection: Domestic Institutions and Trade Policy in Democracies." International Organization 61 (3): 571-605.

Evans, Carolyn L. 2009. "A Protectionist Bias in Majoritarian Politics: An Empirical Investigation." Economics 83 Politics 21 (2): 278-307.

Gilligan, Michael J. 1997. "Lobbying as a Private Good with Intra-Industry Trade." International Studies Quarterly 41 (3): 455-474. 
Grossman, Gene M., and Elhanan Helpman. 1994. "Protection for Sale." The American Economic Review 84 (4): 833-850.

Grossman, Gene M, and Elhanan Helpman. 2005. "A Protectionist Bias in Majoritarian Politics." The Quarterly Journal of Economics 120 (4): 1239-1282.

Hainmueller, J., and M. Hiscox. 2006. "Learning to Love Globalization: The Effects of Education on Individual Attitudes towards International Trade." International Organization 60 (2): 469-498.

Helpman, Elhanan. 1999. "The Structure of Foreign Trade." Journal of Economic Perspectives 13 (2): 121-144.

Hiscox, Michael J. 2001. "Class Versus Industry Cleavages: Inter-Industry Factor Mobility and the Politics of Trade." International Organization 51 (1): 1-46.

Hiscox, Michael J. 2006. "Through a Glass and Darkly: Attitudes toward International Trade and the Curious Effects of Issue Framing." International Organization 60 (3): 755-780.

Hollyer, James R., and B. Peter Rosendorff. 2012. "Leadership Survival, Regime Type, Policy Uncertainty and PTA Accession." International Studies Quarterly 56 (4): 748-764.

Kono, Daniel Y. 2006. "Optimal Obfuscation: Democracy and Trade Policy Transparency." American Political Science Review 100 (3): 369-384.

Leamer, Edward E. 1984. Sources of International Comparative Advantage: Theory and Evidence. Cambridge: MIT Press.

Lohmann, Susanne, and Sharyn O'Halloran. 1994. "Divided Government and U.S. Trade Policy: Theory and Evidence." International Organization 48 (4): 595-632.

Maggi, Giovanni, and Andres Rodriguez-Clare. 1998. "The Value of Trade Agreements in the Presence of Political Pressures." Journal of Political Economy 106 (3): 574-601.

Mansfield, Edward D., and Diana C. Mutz. 2009. "Support for Free Trade: Self-Interest, Sociotropic Politics, and Out-Group Anxiety." International Organization 63 (03): 425457.

Mansfield, Edward D., and Helen V. Milner. 2012. Votes, Vetoes, and the Political Economy of International trade Agreements. Cambridge: Cambridge University Press.

Mansfield, Edward D., Helen V. Milner, and B. Peter Rosendorff. 2000. "Free to Trade: Democracies, Autocracies and International Trade." American Political Science Review 94 (2): 305-322.

Mansfield, Edward D., Helen V. Milner, and B. Peter Rosendorff. 2002. "Why Democracies Cooperate More: Electoral Control and International Trade Agreements." International Organization 56 (3): 477-514. 
Mansfield, Edward D., Helen V. Milner, and Jon C. Pevehouse. 2007. "Vetoing Co-operation: The Impact of Veto Players on Preferential Trading Arrangements." British Journal of Political Science 37 (3): 403-32.

Mansfield, Edward D., and Jon C. Pevehouse. 2006. "Democratization and International Organizations." International Organization 60 (1): 137-167.

Martin, Lisa. 2000. Democratic Commitments: Legislatures and International Cooperation. Princeton: Princeton University Press.

Martin, Lisa. 2005. "The President and International Commitments: Treaties as Signaling Devices." Presidential Studies Quarterly 35 (3): 440-465.

Mayda, Anna Maria, and Dani Rodrik. 2005. "Why are some people (and countries) more protectionist than others?" European Economic Review 49 (6): 1393 - 1430.

McGillivray, Fiona. 1997. "Party Discipline as a Determinant of the Endogenous Formation of Tariffs." American Journal of Political Science 41 (2): 584-607.

McGillivray, Fiona, and Alastair Smith. 1997. "Institutional determinants of trade policy." International Interactions 23 (2): 119-143.

Melitz, Marc J. 2003. "The Impact of Trade on Intra-Industry Reallocations and Aggregate Industry Productivity." Econometrica 71 (6): 1695-1725.

Milner, Helen. 1999. "The Political Economy of International Trade." Annual Review of Political Science 2: 91-114.

Milner, Helen V. 1988. Resisting Protectionism: Global Industries and Politics of International Trade. Princeton: Princeton University Press.

Milner, Helen V., and B. Peter Rosendorff. 1997. "Democratic Politics and International Trade Negotiations: Elections and Divided Government as Constraints on Trade Liberalization." Journal of Conflict Resolution 41 (1): 117-147.

Milner, Helen V., B. Peter Rosendorff, and Edward D. Mansfield. 2004. "International Trade and Domestic Politics: The Domestic Sources of International Trade Agreements and Institutions." In The Impact of International Law on International Cooperation: Theoretical Perspectives, ed. Eyal Benvenisti, and Moshe Hirsch. New York: Cambridge University Press.

Milner, Helen V., and Benjamin Judkins. 2004. "Partisanship, Trade Policy, and Globalization: Is There a Left-Right Divide on Trade Policy?" International Studies Quarterly 48 (1): $95-120$.

Milner, Helen V., and Keiko Kubota. 2005. "Why the Move to Free Trade? Democracy and Trade Policy in the Developing Countries." International Organization 59 (1): 107-143. 
Mitra, Devashish. 1999. "Endogenous Lobby Formation and Endogenous Protection: A Long-Run Model of Trade Policy Determination." American Economic Review 89 (5): 1116-1134.

Mitra, Devashish. 2000. "On the Endogenous Choice between Protection and Promotion." Economics 8 Politics 12 (1): 33-51.

Olson, Mancur. 1965. The Logic of Collective Action: Public Goods and the Theory of Groups. Cambridge: Harvard University Press.

Pelc, Krzysztof. 2012. "Googling the WTO: What Search Engine Data Tell Us About the Political Economy of Institutions." International Organization 67 (3).

Persson, Torsten, and Guido Tabellini. 2000. Political Economics: Explaining Economic Policy. Cambridge: MIT Press.

Rickard, Stephanie J. 2012. "A Non-Tariff Protectionist Bias in Majoritarian Politics: Government Subsidies and Electoral Institutions." International Studies Quarterly 56 (4): $777-785$.

Rogowski, Ronald. 1987. "Trade and the Variety of Democratic Institutions." International Organization 41 (2): 203-223.

Rosendorff, B. Peter. 1996. "Voluntary Export Restraints, Antidumping Procedure and Domestic Politics." American Economic Review 86 (3): 544-561.

Rosendorff, B. Peter. 2005. "Stability and Rigidity: Politics and the Design of the WTO's Dispute Resolution Procedure." The American Political Science Review 99 (3): 389-400.

Rosendorff, B. Peter. 2006. "Do Democracies Trade More Freely?" In Democratic Foreign Policy Making: Problems of Divided Governemnt and International Cooperation, ed. Robert Pahre. London: Palgrave.

Rosendorff, B. Peter, and Helen V. Milner. 2001. "The Optimal Design of International Trade Institutions: Uncertainty and Escape." International Organization 55 (4): 829-857.

Scheve, Kenneth, and Mathew J. Slaughter. 2001. "What Determines Individual TradePolicy Preferences?" Journal of International Economics 54 (1): 267-292.

Staiger, Robert W., and Guido Tabellini. 1987. "Discretionary Trade Policy and Excessive Protection." American Economic Review 77 (5): 823-837.

Yeaple, Stephen Ross. 2005. "A Simple Model of Firm Heterogeneity, International Trade, and Wages." Journal of International Economics 65 (1): 1 - 20. 